\title{
PENERAPAN MODEL PEMBELAJARAN CHILDREN LEARNING IN SCIENCE (CLIS) BERBANTUAN MULTIMEDIA UNTUK MENINGKATKAN PENGUASAAN KONSEP FISIKA SISWA SMA
}

\author{
Ali Ismail M.Pd
}

\begin{abstract}
ABSTRAK
Tujuan penelitian ini adalah untuk mengetahui peningkatan penguasaan konsep dan keterampilan proses sains fisika siswa setelah diterapkan model pembelajaran Children Learning In Science (CLIS) berbantuan multimedia pada pokok bahasan fluida. Penelitian ini menggunakan desain penelitian randomized control group Pretest-Potstest design dengan sampel eksperimen kelas XI di salah satu SMA di Kabupaten Garut. Hasil penelitian menunjukan bahwa penguasaan konsep setelah diterapkan model pembelajaran Children Learning In Science (CLIS) meningkat secara signifikan dilihat dari nilai gainnya. Berdasarkan hasil analisis data diperoleh rata-rata N-gain penguasaan konsep $63 \%$ untuk kelas eksperimen dan 52\% untuk kelas kontrol. Dapat disimpulkan bahwa model pembelajaran Children Learning In Science (CLIS) dapat lebih meningkatkan penguasaan konsep siswa di bandingkan dengan pembelajaran konvensional berbantuan multimedia.
\end{abstract}

Kata Kunci: model pembelajaran Children Learning In Science (CLIS), penguasaan konsep Multimedia.

\section{PENDAHULUAN}

Secara rinci, fungsi dan tujuan mata pelajaran Fisika di tingkat Sekolah Menengah Atas (SMA) adalah sebagai sarana :

1. menyadarkan keindahan dan keteraturan alam untuk meningkatkan keyakinan terhadap Tuhan Yang Maha Esa,

2. memupuk sikap ilmiah, yang mencakup; jujur dan obyektif terhadap data, terbuka dalam menerima pendapat berdasarkan bukti-bukti tertentu, kritis terhadap pernyataan ilmiah, dan dapat bekerja sama dengan orang lain,

3. memberi pengalaman untuk dapat mengajukan dan menguji hipotesis melalui percobaan; merancang dan merakit instrumen percobaan, mengumpulkan, mengolah, dan menafsirkan data, menyusun laporan, serta mengkomunikasikan hasil percobaan secara tertulis dan lisan,
4. mengembangkan kemampuan berpikir analisis induktif dan deduktif dengan menggunakan konsep dan prinsip Fisika untuk menjelaskan berbagai peristiwa alam dan menyelesaikan masalah baik secara kualitatif maupun kuantitatif,

5. menguasai pengetahuan, konsep, hukum-hukum dan prinsip Fisika, serta memiliki pengetahuan, keterampilan dan sikap ilmiah (Depdiknas, 2006).

Dari uraian di atas tampak bahwa penyelenggaraan mata pelajaran Fisika di SMA dimaksudkan sebagai wahana atau sarana untuk melatih para siswa agar dapat menguasai konsep dan prinsip Fisika, memiliki kecakapan ilmiah, memiliki keterampilan proses sains dan keterampilan berpikir kritis dan kreatif. Agar mata pelajaran Fisika dapat benarbenar berperan seperti demikian, maka tak dapat ditawar lagi bahwa pembelajaran Fisika harus dikonstruksi sedemikian 
rupa, sehingga proses pendidikan dan pelatihan berbagai kompetensi tersebut dapat benar-benar terjadi dalam prosesnya

Kenyataan di lapangan, proses pembelajaran Fisika dirasa masih jauh dari apa yang diharapkan. Dari pengamatan langsung peneliti di salah satu SMA di kabupaten Garut diperoleh bahwa sebagian besar proses pembelajaran Fisika dilaksanakan dengan menggunakan pembelajaran satu arah yang lebih menekankan pada penyampaian materi pembelajaran (metode konvensional). pada metode ini keterlibatan siswa secara aktif dalam proses belajar mengajar masih kurang. Kelemahan dalam penggunaan metode konvensional adalah pengajarannya yang terlampau matematis. Siswa cenderung dituntut untuk menghapal rumus dan penggunaan rumus tersebut tanpa memahami konsep-konsep yang melatarbelakangi terbentuknya rumus tersebut, sehingga siswa pun sulit menyerap konsep-konsep fisisnya. Hal ini berdampak pada rendahnya hasil penguasaan konsep fisika yang dicapai siswa. Seperti ditunjukkan oleh rata-rata nilai ulangan harian untuk materi sebelumnya hanya 5,2 .

Selain itu pembelajaran secara konvensional ini kurang dapat menumbuhkan keterampilan proses sains siswa, karena pembelajaran difokuskan pada aspek kognitif, sedangkan aspek psikomotorik dan aspek afektif kurang diperhatikan. Hal ini menyebabkan kesempatan siswa untuk terlibat dalam proses belajar dan kesempatan untuk mengembangkan diri berkurang.

Salah satu pembelajaran yang dipandang dapat membantu dan memfasilitasi untuk memudahkan siswa dalam menguasai sains Fisika dan berlatih mengembangkan keterampilan proses sains dan penguasaan konsep adalah model pembelajaran children learning in science (CLIS). Model pembelajaran
CLIS adalah kerangka berpikir untuk menciptakan lingkungan yang memungkinkan terjadinya kegiatan belajar mengajar yang melibatkan siswa dalam kegiatan pengamatan dan percobaan dengan menggunakan Lembar Kerja Siswa (LKS).

Pada saat ini kita juga sedang memasuki era informasi. Teknologi dan komunikasi (TIK) yang terus berkembang dan cenderung akan terus mempengaruhi segenap kehidupan manusia.Perkembangan di bidang teknologi informasi dan komunikasi yang sangat cepat ini berpengaruh juga terhadap pribadi, aktivitas, kehidupan ataupun cara berpikir. Perkembangan ini perlu juga dikenalkan pada siswa agar mereka mempunyai bekal pengetahuan dan pengalaman untuk menerapkan dan menggunakan TIK dalam kegiatan belajar mengajar. Dalam proses pembelajaran saat ini banyak dikembangkan mediamedia pembelajaran berbasis komputer, salah satunya pembuatan dan pengembangan software dalam media pembelajaran

Perkembangan TIK ini memungkinkan dihasilkannnya berbagai multimedia dalam pembelajaran yang dapat memudahkan dan membangkitkan motivasi belajar siswa dalam mempelajari konsep Fisika. Menurut beberapa penelitian diantaranya yang di ungkapkan Wiendartun, Taufik dan Hery (2007) mengungkapkan bahwa, pembelajaran berbasis multimedia dapat meningkatkan hasil belajar siswa.

Berdasarkan pemaparan di atas, maka penulis memandang perlu untuk melakukan sebuah penelitian mengenai "penerapan model pembelajaran children learning in science (CLIS) berbantuan multimedia untuk meningkatkan penguasaan konsep siswa pada pokok bahasan fluida". 
Berdasarkan latar belakang masalah yang telah diuraikan di atas, maka permasalahan dalam penelitian ini dapat dirumuskan dalam bentuk pertanyaan sebagai berikut: "apakah model pembelajaran children learning in science (CLIS) berbantuan multimedia dapat lebih meningkatkan penguasaan konsep siswa dibandingkan pembelajaran konvensional berbantuan multimedia?".

Untuk lebih mengarahkan penelitian, maka rumusan masalah di atas dijabarkan menjadi beberapa pertanyaan penelitian sebagai berikut:

1. Bagaimanakah perbandingan peningkatan penguasaan konsep siswa antara yang mendapatkan model pembelajaran children learning in science (CLIS) berbantuan multimedia dengan yang mendapatkan pembelajaran konvensional berbantuan multimedia?

\section{KERANGKA TEORITIS}

\section{Pengertian Model Pembelajaran Children Learning In Science (CLIS)}

Model pembelajaran CLIS adalah kerangka berpikir untuk menciptakan lingkungan yang memungkinkan terjadinya kegiatan belajar mengajar yang melibatkan siswa dalam kegiatan pengamatan dan percobaan dengan menggunakan

LKS.ModelpembelajaranCLIS bertujuan membentuk pengetahuan (konsep) ke dalam memori siswa agar konsep tersebut dapat bertahan lama, karena model pembelajaran CLIS memuat sederetan tahap-tahap kegiatan siswa dalam mempelajari konsep yang diajarkan.

Menurut Driver (1988) tahapantahapan CLIS secara umum CLIS terdiri dari beberapa tahap diantaranya

1. Orientasi

2. Pemunculan gagasan awal
3. Penyusunan gagasan

4. Penerapan gagasan

5. Kaji ulang perubahan gagasan

Berdasarkan tahapan-tahapan yang dilaksanakan pada model pembelajaran CLIS maka dapat dikemukakan karakteristik model pembelajaran CLIS antara lain:

1. Dilandasi oleh pandangan konstruktivisme

2. Pembelajaran berpusat pada siswa

3. Melakukan aktifitas hands on/ minds on

4. Menggunakan lingkungan sebagai sumber belajar

Faktor-faktor penting dalam pelaksanaan pembelajaran model pembelajaran CLIS ini adalah:

1. Menciptakan situasi belajar terbuka dan memberikan kebebasan pada siswa dalam mengemukakan ide atau gagasan.

2. Memberikan kesempatan pada siswa untuk bertanya pada teman atau gurunya, kemudian pada akhir kegiatan pembelajaran guru menjelaskan konsep-konsep ilmiah untuk menghidari miskonsepsi pada siswa.

3. Memberikan tugas perorangan yang dikerjakan siswa dirumah berupa PR sebagai penerapan konsep.

Kelebihan-kelebihan CLIS sebagai berikut :

1. Gagasan anak lebih mudah dimunculkan.

2. Membiasakan siswa untuk belajar mandiri dalam memecahkan suatu masalah.

3. Empat syarat perubahan konsepsi yang dikemukakan oleh posner etal terpenuhi.

4. Menciptakan kreatifitas siswa untuk belajar sehingga tercipta suasana kelas yang lebih nyaman dan kreatif,terjadi kerjasama sesama siswa dan siswa terlibat langsung dalam melakukan kegiatan. 
5. Menciptakan belajar yang lebih bermakna karena timbulnya kebanggaan siswa menemukan sendiri konsep ilmiah yang dipelajari.

6. Guru mengajar akan lebih efektif karena dapat menciptakan suasana belajar yang aktif

Adapun kelemahan CLIS adalah sarana laboratorium harus lengkap, kemudian siswa yang belum terbiasa belajar mandiri atau berkelompok akan merasa asing dan sulit untuk menguasai konsep.

\section{Pengertian Pembelajaran Konvensional(Metode Ceramah).}

Pada pembelajaran konvensional dengan metode ceramah guru memberikan penerangan atau penuturan secara lisan kepada sejumlah siswa. Siswa mendengarkan dan mencatat seperlunya. Pada umumnya siswa menerima saja apa yang dijelaskan oleh guru. Dalam pembelajaran dengan metode ini guru memegang peran sebagai sumber informasi bagi siswa. Guru lebih mendominasi proses pembelajaran yang meliputi menerangkan materi pelajaran, memberikan contoh-contoh memandu penyelesaian soal serta menjawab semua pertanyaan yang diajukan siswa.

Seperti metode-metode lainnya, metode pembelajaran konvensional ini memiliki keunggulan dan kelemahan. Menurut (Wartono, 1996) keunggulan dari metode ini adalah dapat digunakan untuk siswa dalam jumlah yang besar dan dapat menyelesaikan suatu materi pelajaran dengan cepat. Sedangkan kelemahan-kelemahan dari pembelajaran ini antara lain:

1. Siswa seringkali tidak aktif dalam proses pembelajaran, sehingga pembelajaran jadi kurang efektif.

2. Terutama bagi siswa yang belum cukup dewasa, pembelajaran konvensional ini sering menimbulkan kebosanan .
3. Terutama untuk pendidikan sains bagi siswa yang masih muda pembelajaran ini tidak sesuai dengan tuntutan tujuan pendidikan sains yang modern, yang antara lain menuntut adanya pendidikan tentang metode ilmiah dan sikap ilmiah dalam pendidikan sains, sains bukan hanya mengajarkan fakta tetapi juga harus melatih keterampilan dan kecakapan.

Berikut ini perbedaan sintak pembelajaran CLIS dengan pembelajaran konvensional :

\section{Tabel 1}

Perbedaan Model CLIS dengan pembelajaran konvensional

\begin{tabular}{|c|c|c|}
\hline Perbedaan & CLIS & $\begin{array}{l}\text { Pembelajaran } \\
\text { konvensional }\end{array}$ \\
\hline $\begin{array}{l}\text { Kegiatan } \\
\text { awal }\end{array}$ & $\begin{array}{l}\text { a. Guru } \\
\text { mengecek } \\
\text { kehadiran } \\
\text { siswa } \\
\text { Fase 1: orientasi } \\
\text { a. Guru } \\
\text { melakukan } \\
\text { apesepsi dan } \\
\text { menghadapk } \\
\text { an siswa } \\
\text { pada } \\
\text { fenomena } \\
\text { alam yang } \\
\text { sering di } \\
\text { jumpai } \\
\text { Fase } 2 \\
\text { Pemunculan } \\
\text { gagasan awal } \\
\text { a. Guru } \\
\text { menggali } \\
\text { konsepsi } \\
\text { awal siswa }\end{array}$ & $\begin{array}{l}\text { a. Mengkondisikan } \\
\text { siswa. } \\
\text { b. Menyampaikan } \\
\text { tujuan } \\
\text { pembelajaran. }\end{array}$ \\
\hline $\begin{array}{l}\text { Kegiatan } \\
\text { inti }\end{array}$ & $\begin{array}{l}\text { Fase } \\
\text { penyusunan } \\
\text { gagasan } \\
\text { a. Siswa } \\
\text { menggunaka } \\
\text { n teori untuk } \\
\text { berhipotesis } \\
\text { b. Guru } \\
\text { mengajak } \\
\text { siswa } \\
\text { berkelompok } \\
\text { untuk } \\
\text { melakukan } \\
\text { eksperimen }\end{array}$ & $\begin{array}{l}\text { a. Guru } \\
\text { menerangkan } \\
\text { suatu konsep, } \\
\text { b. Siswa bertanya } \\
\text { hal-hal yang } \\
\text { tidak dimengerti } \\
\text { c. Guru soal } \\
\text { memberikan } \\
\text { contoh mep } \\
\text { aplikasi konsep } \\
\text { d. Guru meminta } \\
\text { siswa untuk } \\
\text { mengerjakan } \\
\text { latihan soal dari }\end{array}$ \\
\hline
\end{tabular}




\begin{tabular}{|c|c|c|}
\hline Perbedaan & CLIS & $\begin{array}{l}\text { Pembelajaran } \\
\text { konvensional }\end{array}$ \\
\hline & $\begin{array}{l}\text { c. Siswa } \\
\text { melakukan } \\
\text { eksperimen } \\
\text { untuk } \\
\text { membuktikan } \\
\text { hipotesisnya } \\
\text { d. Siswa } \\
\text { diminta } \\
\text { untuk } \\
\text { menghubung } \\
\text { kan hasil } \\
\text { eksperimen } \\
\text { dengan } \\
\text { hipotesis } \\
\text { Fase } 4 \\
\text { penerapan } \\
\text { gagasan } \\
\text { a. Siswa di } \\
\text { minta } \\
\text { menjawab } \\
\text { pertanyaan- } \\
\text { pertanyan di } \\
\text { LKS } \\
\text { b. Dengan } \\
\text { bimbingan } \\
\text { guru, siswa } \\
\text { mendiskusika } \\
\text { n hasil } \\
\text { eksperimen }\end{array}$ & $\begin{array}{l}\text { buku paket } \\
\text { e. Siswa mencatat } \\
\text { materi yang } \\
\text { diterangkan dan } \\
\text { diberi soal-soal } \\
\text { pekerjaan rumah. }\end{array}$ \\
\hline Penutup & $\begin{array}{l}\text { Fase } 5 \text { : kaji } \\
\text { ulang } \\
\text { perubahan } \\
\text { gagasan } \\
\text { a. Guru } \\
\text { memberikan } \\
\text { pertanyaan } \\
\text { lisan atau } \\
\text { kuis untuk } \\
\text { mengevaluasi } \\
\text { apa yang } \\
\text { telah } \\
\text { diperoleh } \\
\text { siswa selama } \\
\text { proses } \\
\text { pembelajaran }\end{array}$ & $\begin{array}{l}\text { Mengecek } \\
\text { pemahaman dan } \\
\text { memberikan umpan } \\
\text { balik. }\end{array}$ \\
\hline
\end{tabular}

\section{METODOLOGI PENELITIAN}

Penelitian ini menggunakan metodekuasi eksperimen(eksperimen semu) dan deskriptif. Metode eksperimen semu digunakan untuk mengetahui perbandingan peningkatan keterampilan proses sains dan penguasaan konsep siswa antara siswa yang mendapatkan pembelajaran dengan model pembelajaran children learning in science (CLIS) berbantuan multimedia danyang mendapatkan pembelajaran dengan pembelajaran konvensional berbantuan multimedia. Metode deskriptif digunakan untuk mengetahui gambaran tentang tanggapan siswa terhadap model pembelajaran CLIS berbantuan multimedia yang diterapkan..

Desain eksperimen yang digunakan adalah "The randomizedPretest-Posttest control group design"dimana penentuan kelas kontrol dan eksperimen dilakukan secara acakperkelas.Eksperimen dilakukan dengan memberikan perlakuan pembelajaran dengan model pembelajaran CLIS berbantuan multimedia pada kelompok eksperimen dan pembelajaran konvensional berbantuan multimedia pada kelompok kontrol.

\section{HASIL DAN PEMBAHASAN}

\section{Peningkatan Penguasaan Konsep}

Penguasaankonsep siswa terhadap materi fluida statis diukur dengan tes pilihan ganda sebanyak 15 soal. Data Perbandingan nilai rata-rata tes awal, tes akhir dan gain yang dinormalisasi (dalam persen) antara kelas eksperimen dan kelas kontrol ditunjukkan pada Gambar d bawah ini

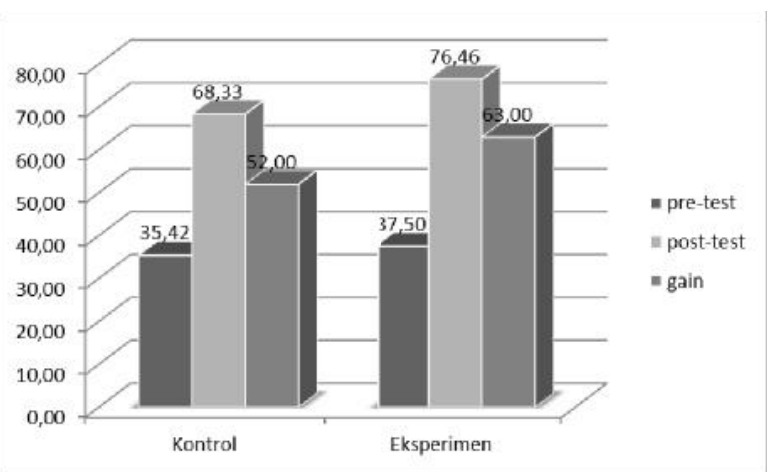

Gambar 1.1Diagram Batang

Perbandingan Nilai Rata-Rata Tes Awal, Tes Akhir dan Gain yang Dinormalisasi
Berdasarkan
Gambar

di

atas.diperoleh bahwa tes awal penguasaan 
konsep yang diberikan kepada siswa menunjukkan bahwa siswa kelas kontrol dan siswa kelas eksperimen memiliki tingkat penguasaan konsep yang sama sebelum pembelajaran. Setelah diberikan perlakuan yang sedikit berbeda kepada kedua kelompok kelas ini, tes akhir dengan soal yang sama dengan tes awal kembali diujikan kepada siswa, dan ternyata skor tes penguasaan konsep kelas kontrol dengan kelas eksperimen sebelum dan sesudah perlakuan mengalami peningkatan dengan indeks peningkatan yang berbeda, dimana rata-rata peningkatan kelas eksperimen lebih tinggi dibandingkan kelas kontrol. Rata-rata skor post test penguasaan konsep kelas eksperimen lebih tinggi dibandingkan kelas kontrol. Selain itu dari gambar diatas d peroleh kesimpulan bahwa nilai rata-rata gain yang dinormalisasi untuk kelas eksperimen ialah 0,63 dengan kategori sedang dan nilai rata-rata gain yang dinormalisasi untuk kelas kontrol ialah 0,52 dengan kategori sedang. Perbandingan nilai ini secara langsung menunjukkan bahwa penggunaan model pembelajaranChildren Learning in Science (clis)berbantuan multimedia dapat lebih efektif meningkatkan penguasaan konsep siswa pada konsep fluida statis dibandingkan dengan pembelajarn konvensional berbantuan multimedia.

Indikator penguasaan konsep dalam penelitian ini didasarkan pada tingkatan domain kognitif Bloom yang dibatasi pada tingkatan domain hapalan (C1), pemahaman (C2), penerapan (C3) dan analisis (C4). Perbandingan rata-rata Ngain untuk setiap indikator penguasaan konsep ditunjukkan oleh diagram batang pada Gambar d bawah ini

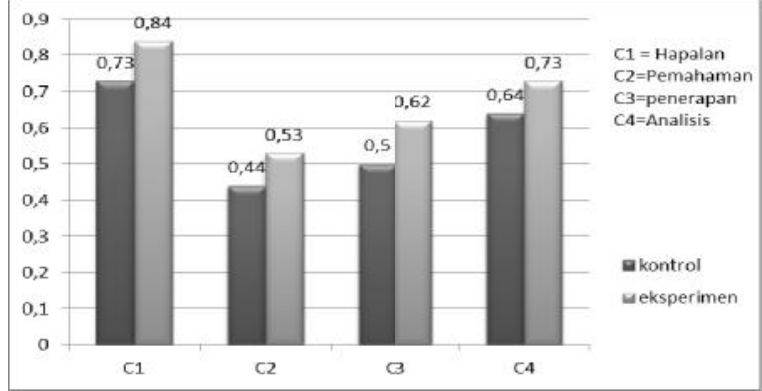

Gambar 1.2 Diagram Batang

Perbandingan $\mathrm{N}$-gain Indikator Penguasaan

Konsep antara Kelas Eksperimen dan Kelas Kontrol

Berdasarkan Gambar atas perolehan rata-rata gain yang dinormalisasi penguasaan konsep siswa untuk setiap ranah kognitif pada pembelajaran dengan model CLIS berbantuan multimedia lebih tinggi dibandingkan dengan pembelajaran konvensional berbantuan multimedia.

Konsep fluida statis yang dibahas dalam penelitian ini terdiri dari tiga label konsep (sub pokok bahasan) yaitu tekanan hidrostatis, hukum pascal dan hukum archimedes. Dari Tabel 1.3 menunjukkan prosentase nilai rata-rata $\mathrm{N}$-gain subkonsep dari materi fluida statis untuk kelas eksperimen lebih tinggi dari pada kelas kontrol.Perbandingan $\mathrm{N}$-gain untuk setiap label konsep ditunjukkan oleh diagram batang pada Gambar 1.3.

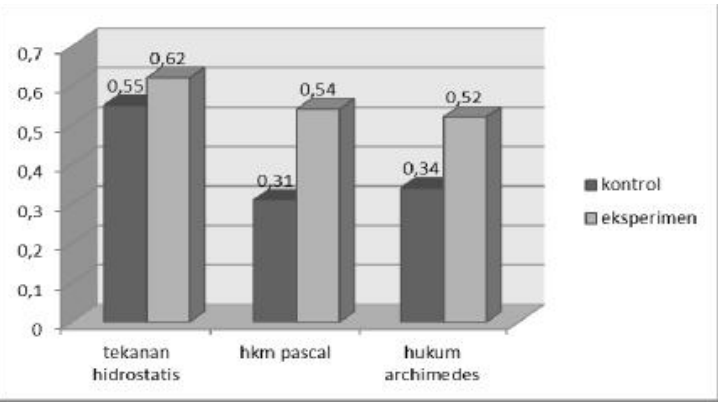

Gambar 1.3. Diagram Batang Perbandingan N-Gain untuk Setiap Label

Konsep antara Kelas Eksperimen dan Kelas Kontrol 
Penggunaan model pembelajaran CLIS ternyata lebih mampu meningkatkan penguasaan konsep siswa terhadap materi yang diajarkan. Hal ini disebabkan karena pada model pembelajaran CLIS, siswa diajak untuk mencari konsep melalui percobaan sehingga tidak hanya transfer informasi dari guru terhadap siswa.

Hasil pengujian hipotesis menunjukkan bahwa penerapan model pembelajaran CLIS lebih efektif dalam meningkatkan penguasaan konsep dibandingkan penerapan model pembelajaran konvensional. Model CLIS yang diterapkan pada kelas eksperimen dapat menggali pengalaman siswa sebagai modal dasar dalam penemuan konsepkonsep baru. Hal ini senada dengan pernyataan Ausubel (Dahar, 1989) yang menyatakan bahwa agar sebuah pembelajaran menjadi bermakna, maka konsep baru atau informasi baru yang hendak diperoleh siswa harus dikaitkan dengan konsep-konsep yang telah ada dalam struktur kognitif siswa. Selain itu, model pembelajaran CLIS melatih kemampuan siswa untuk merumuskan hipotesis melalui kegiatan percobaan, sehingga setelah melalui proses pembelajaran ini siswa dapat memahami konsep yang dipelajari.

Berdasarkan perbandingan rata-rata $\mathrm{N}$-gain penguasaan konsep kalor antara kelas eksperimen dan kontrol, menunjukkan bahwa penerapan model pembelajaran CLIS lebih efektif secara signifikan dalam meningkatkan penguasaan konsep dibanding penerapan model pembelajaran konvensional.

\section{KESIMPULAN}

Berdasarkan data dan analisis hasil penelitian yang telah dilakukan tentang model pembelajaran children learning in science (CLIS) pada pembelajaran fluida statis untuk mengembangkan keterampilan proses sains dan penguasaan konsep konsep dapat disimpulkan bahwa:
1. Model Pembelajaran CLIS secara signifikan dapat lebih meningkatkan penguasaan konsep siswa pada materi fluida statis dibandingkan dengan model pembelajaran konvensional

\section{DAFTAR PUSTAKA}

Dahar, R Wilis. (1989). Teori-teori Belajar. Jakarta: Erlangga.

Depdiknas.(2006). Kurikulum Tingkat Satuan Pendidikan Sekolah Menengah Atas. Jakarta: Depdiknas.

Driver.R. (1988). "changing conceptions". Journal research in education 161196.

Rustaman, N dan Rustaman, A. (1997), Pokok-Pokok Pengajaran Biologi dan Kurikulum 1994. Jakarta: Pusbuk Depdikbud.

Wiendartun, Taufik dan Hery (2007). "Pengaruh Pembelajaran Berbasis Multimedia Terhadap Hasil Belajar Fisika" bandung :Proceeding of The First International Seminar on Science 